\title{
11. 腎移植における内科医の役割
}

\author{
名古屋第二赤十字病院腎臟内科 両角 國男
}

腎移植における内科医の役割を主に腎臓内科 の立場から考察する.

腎蔵内科医の究極の目標は腎不全への進行阻 止である. しかし, 未期腎不全への進行が避け られない状況において末期腎不全治療法として, 血液透析, 腹膜透析と腎移植の 3 つを適切に紹 介し, 治療選択の援助をすることが重要である. 日本腎臓学会を中心にわかりやすい説明用冊子 が作成され, 各治療法の特徵と利点などが記載 されている. 腎移植手術の概要, 免疫抑制療法, 移植後の合併症や生活などを説明する. ABO 血液型不適合でも腎移植は可能なこと, 透析療 法に導入しないpreemptive腎移植が可能なこと なども説明するが, 最新の腎移植成績などを理 解する必要がある.

腎移植手術前にドナーとレシピエントの腎機 能と全身評価を行い腎移植後の合併症を回避・ 軽減することを目指す。移植手術前から体重, 血圧, 食事など自己管理の重要性を理解しても らい腎移植後の生活習慣病対策を始める。高血
圧対策, 肥满防止, 脂質や血糖管理を行うこと が移植腎長期予後向上には不可欠である.

腎移植手術後には, 免疫抑制療法に伴う内科 的合併症の予防と治療を担当する. 周術期管理 は移植外科チームが担当し, 外科側と内科側が 協力しながら早期治療を行い, 外来移行後の慢 性期管理を内科が主に担当している移植施設が 多い.

内科医は, 移植腎に出現する種々の移植腎障 害の診断と治療を行うが, 確定診断には移植腎 生検による病理診断が必要となる。この領域も 内科が担当する.

腎移植により腎不全から完全に回復した腎臓 を再び腎不全に陥らせないための総合管理が内 科医の大きな役割である. 脳死法案が改定され 2010 年 7 月に発効するが, わが国で少ない献腎 移植, 脳死下臓器提供を推進させ, 末期腎不全 患者のより多くが腎機能を回復し, 高いQOL の社会復帰できるよう社会に働きかけることが 内科医の役割として今後は重要となる.

\section{2. $\mathrm{COPD}$ の病型分類と薬物治療の進歩}

\section{京都大学大学院医学研究科呼吸器内科学 三嶋 理晃}

日本呼吸器学会「COPDの診断と治療のガイド ライン」が 5 年ぶりに改訂され (第 3 版), 2009 年に発表された。ここでは, 最近のCOPD診療の 進歩を取り入れたこのガイドラインの内容を参 考にしながら, 病型分類と薬物療法を中心とし たCOPD診療の最前線を紹介する.

COPDの診断には気管支拡張薬投与後の 1 秒率 が 70 未満の閉塞性換気障害を有し, 他の閉塞性
障害を来たし得る疾患を除外することが必要で ある.特に気管支喘息との鑑別が重要であるが, 鑑別が困難な場合が多い. COPDは肺気腫病変主 体の「肺気腫型」と, 肺気腫病変を持たない「非 気腫型」の 2 病型に区別される.この病型の区 別や他疾患との鑑別に胸部X線CTは重要な役割 を果たす。病期分類は $\% 1$ 秒量でなされるが, COPDの重症度は\%1秒量に加えて, 体重, 呼吸 
困難の程度などによって総合的に評価される。 さらに, 高次神経機能障害, 消化器障害, 心血 管障害, 睡眠障害, 消耗性障害・代謝性障害な どの合併症の存在がCOPDの臨床像に重要な役割 を演じる。

COPDの管理指針としては, COPODの重症度 が上がるに従って, 禁煙, インフルエンザワク チン接種, 気管支拡張薬の投与, リハビリテー ションの施行などが追加されていく,「アド・オ ンの原則」が適用される. 薬物療法としては,
長時間作用性抗コリン薬または長時間作用性 $\beta 2$ 刺激薬 $(\mathrm{LABA})$ の単独もしくは併用療法に適宜 テオフィリンを加える. 吸入ステロイド/LABA の配合吸入薬も有効である.さらに, 各種喀痰 調整薬が増悪頻度を有意に減少させることも報 告されている。これらの薬物治療の進歩によっ て, 大規模臨床試験でCOPDの生命予後の延長も 報告されるようになり,「COPD is a preventable and treatable disease」と言われるようになって 来た。

\title{
13. ALI/ARDSの病態と治療一最新の知見
}

\section{慶應義塾大学呼吸循環器内科 長谷川直樹}

急性肺損傷 (ALI) /急性呼吸促迫症候群 (ARDS) は1994 年の米国胸部疾患学会/欧州集中治療医 学会の合同検討会 (AECC) により定められた定 義 (1)急性発症, (2)両側肺浸潤影, (3)酸素化障 害, (4)左房圧の上昇なし, の 4 項目で診断され る非心原性肺水腫である. 様々な先行疾患に合 併する症候群であり, 頻度の高いものとして肺 炎, 誤嚥, sepsis, 外傷などが挙げられる. ALI/ ARDSの主病態は, 肺内あるいは肺外で惹起され た炎症が好中球などの細胞性因子とサイトカイ ンや血液凝固系などの液性因子が肺に誘発する 急性炎症である。感染症では病原体に特異的な 分子構造物質 (pathogen associated molecular pattern : PAMP), 非感染性の外傷や手術侵襲で は壊死細胞から放出される high-morbility group box (HMGB-1) や熱ショックタンパクなどの物 質(alarmin)とこれらを認識する受容体 (patternrecognition receptor : PRR), との関係が明らか にされ，ALI/ARDSの病態解明が進んでいる. 多くの薬物療法が臨床試験では結果を得られず 実用に至っていない. 副腎皮質ステロイドの効 果も否定的であるが我が国では好中球エラスター ゼ阻害物質が利用可能である.今後はALI/ARDS の基礎疾患として最も頻度の高いsepsisの大規模 臨床試験を通してALI/ARDSに有効な薬剤の開 発が期待される。 一方, 人工呼吸がその機械的 ストレスにより barotrauma, volutrauma, atelectraumaに加えてbiotraumaにより炎症を促進す ることが明らかになり,低 1 回換気量 $(6 \mathrm{ml} / \mathrm{kg}$ : 予測体重）と肺の虚脱防止による呼吸管理法が 本疾患の予後改善に寄与した.

\section{4. 内分泌性高血圧の診断と治療のアップデート}

\author{
東京医科歯科大学大学院分子内分泌内科学 平田結喜緒
}

